\title{
Journal of Pediatrics \& Child Care
}

\section{Infancy-Case Report and Review of Literature}

\section{Introduction}

Idiopathic Infantile Arterial calcification of Infancy (IIAC) is one of the rare causes of hypertension in newborns. It is characterized by extensive arterial calcification of large and medium sized arteries and is generally associated with poor prognosis [1]. It is important that physicians be aware of this condition because it can be suspected prenatally and early diagnosis is associated with improvement in survival rates.

We present a case of a preterm infant with pericardial effusion and systemic hypertension along with calcifications detected on prenatal ultrasound (US) and echocardiogram (ECHO).

\section{Case Presentation}

A $2.37 \mathrm{~kg}$ female was born to a G2P2 female at 33 weeks gestation via cesarean section due to fetal decelerations. Infant was appropriate for gestational age. Initial prenatal US showed polyhydramnios, (Amniotic fluid index of $27.9 \mathrm{~cm}$ with the largest pocket measuring $10.1 \mathrm{~cm}$ ) an echo dense aorta and an isolated pericardial effusion measuring $1.7 \mathrm{~cm}$ with no evidence of cardiac structural defects, and a normal middle cerebral artery doppler. Maternal viral serologies were negative for toxoplasmosis, parvovirus, CMV and HSV. Coxsackie antibodies were 1:32 indicative of current or past infection, however no follow up titers were done to establish rising titers.

Infant had APGARS of 2 and 6 at 1 and 5 minutes and was intubated soon after delivery. She received surfactant, umbilical catheters were placed, cultures were drawn and she was started on intravenous fluids and antibiotics (Ampicillin and Gentamicin). Physical exam was significant for low set ears, muffled heart sounds and a 3/6 systolic ejection murmur. Chest X-ray was significant for an enlarged heart occupying majority of the left hemi-thorax and a circular hyper-density (Figure 1) present over the mediastinum. The infant was also noted to be hypertensive (systolic blood pressures ranging from 97-104 $\mathrm{mm} \mathrm{Hg}$ and diastolic blood pressures between 30-41 $\mathrm{mm} \mathrm{Hg} ; \geq 95^{\text {th }}$ percentile for age, [2] (measured via umbilical artery catheter). There was no difference noted in the upper and lower extremity blood pressure. Our workup revealed elevated aldosterone $465 \mathrm{ng} / \mathrm{dl}$ (normal: 5-102 ng/dl) and renin $253 \mathrm{ng} / \mathrm{ml} / \mathrm{hour}$ (normal: 2-35 ng/ml/hour), normal renal US and doppler, normal abdominal US, normal thyroid function test ( TSH 3.50, free T4 1.63), normal 17- hydroxy progesterone $175 \mathrm{ng} / \mathrm{dl}$ (normal: 26-568 ng/dl) and normal Urinary VMA assay with VMA/Creatinine ratio ratio $8 \mathrm{mg} /$ gm (normal 0-27 mg/gm). Chromosomal microarray was sent due to dysmorphic features associated with cardiac anomalies and it revealed 2 variants of unknown significance (VUS): A gain of $586 \mathrm{kbp}$ (0.586 mbp) on chromosome 20q11.21 and another gain of 1,937 kbp (1.937 mbp) on chromosome 16p11.2.
ECHO done immediately after birth, confirmed the presence of a pericardial effusion and an US guided pericardiocentesis was done with removal of 2-3 cc of serous pericardial fluid. Follow up ECHO showed persistence of pericardial effusion, paradoxical septal movement, pulmonary hypertension (estimated right ventricle pressure $60 \mathrm{mmHg}$ ), large patent ductus arteriosus (PDA), mild mitral regurgitation, mild tricuspid insufficiency and a small secundum atrial septal defect. The left ventricle size and function was normal with no hypertrophy noted. In addition, the entire aorta appeared echo dense however the $\mathrm{z}$ scores were normal. The aortic annulus measured 5.5-6.0 $\mathrm{mm}$, ascending aorta $6 \mathrm{~mm}$, transverse arch $3 \mathrm{~mm}$ and descending aorta $3 \mathrm{~mm}$. The $\mathrm{z}$ score was at the $26 \mathrm{th}$

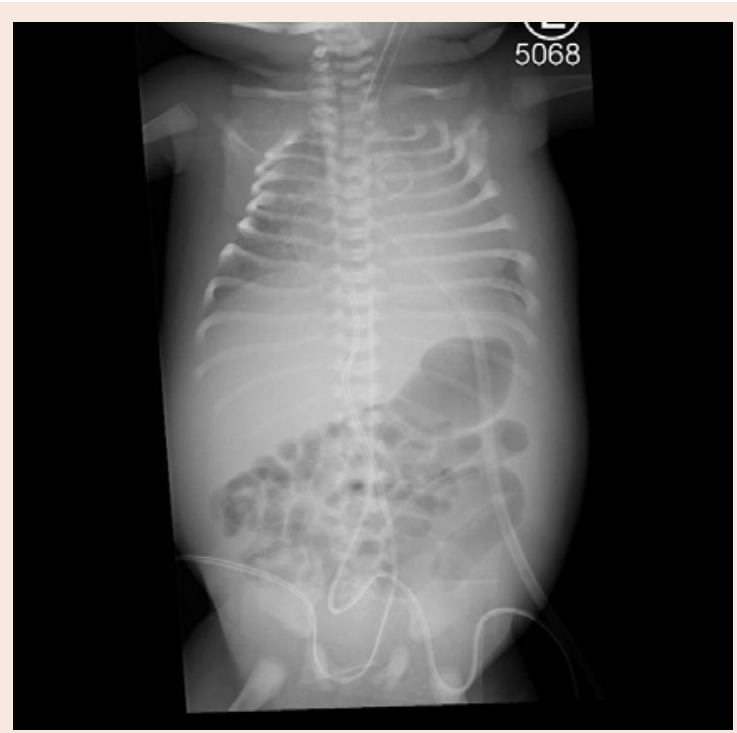

Figure 1: Circular hyper density present over left mediastinum representing calcifications 


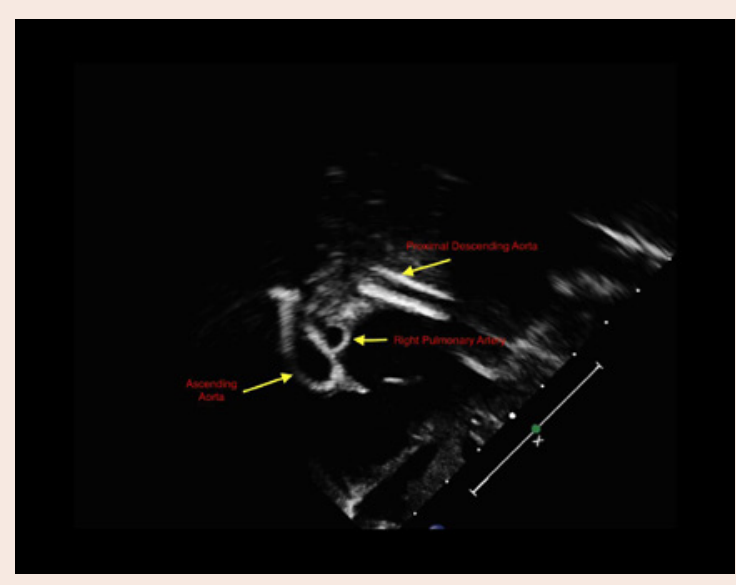

Figure 2: Intraluminal calcification of the ascending aorta, right pulmonary artery and proximal descending aorta

percentile at -0.64 (normal 0.52 to 0.77 ) [3]. These findings were consistent with aortic wall calcification (Figure 2). These findings, in the setting of hypertension were concerning for IIAC. Repeat Chest $\mathrm{X}$-ray continued to show a ring shaped calcified area at the origin of the ascending aorta, consistent with our diagnosis. On day 2 of life, a pericardial window was created, $30 \mathrm{cc}$ of serosanguineous fluid was drained and a pericardial drain was left in place. The infant was treated with bisphosphonates but unfortunately died secondary to cardiac failure. Autopsy was denied by the family.

\section{Pericardial Effusion in Idiopathic Infantile Arterial Calcification}

\section{Case discussion}

Our patient was noted to have systolic hypertension associated with calcifications noted on prenatal US, postnatal ECHO, and chest X-ray. Based on her presentation, she was worked up for the common causes of hypertension. Absence of microscopic hematuria and a normal renal Doppler US ruled out renal artery stenosis. An abdominal US and normal VMA assay ruled out pheochromocytoma. Thyroid function tests and 17-hydroxy progesterone levels were within normal limits making hyperthyroidism and congenital adrenal hyperplasia less likely. The renin and aldosterone levels were increased. This could be due to renal ischemia secondary to hypertension or renal artery calcifications. The congestive heart failure could also have contributed to decreased renal perfusion subsequently stimulating the renin angiotensin system.

Based on our review of literature, her clinical presentation and imaging findings were consistent with the diagnosis of IIAC. Our patient also had pericardial effusion noted prenatally which progressively increased after birth. The pathogenesis of pericardial effusion in IIAC is unclear however we presume that in our patient, it was secondary to pulmonary artery hypertension. One of the leading hypotheses suggests, that in pulmonary hypertension, here is impaired fluid reabsorption of pericardial fluid via the venous or lymphatic channels draining into the right atrium [4]. Therefore, a high right atrial pressure compromises the pericardial fluid drainage, which results in its accumulation. Although pulmonary hypertension has been described many times in previously reported cases of IIAC, the pathogenesis behind it has not been described.

In our patient, VUS were located on chromosome 20q11.21 and 16 11.2, which have not previously been reported in association with IIAC. Micro duplication of $16 \mathrm{p} 11.2$ is known to be associated with problems of development, speech, behavior and learning in addition to birth defects. No particular defect has been reported multiple times, but this is partly because very few cases with this mutation have been described in the medical literature. The birth defects reported with this variant include congenital diaphragmatic hernia, cleft palate, horseshoe kidney, PDA, syringomyelia, pectus carinatum and excavatum, hypospadias and malrotation. (http://www.rarechromo. org/html/home.asp)

\section{Idiopathic Arterial Calcification of infancy-Review of Literature}

IIAC is a rare autosomal recessive genetic disorder, characterized by extensive arterial calcification and stenosis of large and medium sized arteries. It presents in infancy as refractory hypertension or cardiac failure and is associated with a poor prognosis [1]. The dystrophic calcification in IIAC leads to decreased vessel compliance and hypertension. This eventually causes cardiac failure and hypertrophy of the chambers which can present as polyhydramnios, fetal hydrops and rarely death during the third trimester. The stenosis and occlusion of the coronary arteries due to calcification also causes myocardial ischemia resulting in heart failure in infancy [5].

On review of literature, 200 cases have been reported so far with approximately $85 \%$ infants dying within the first 6 months secondary to cardiopulmonary complications [1]. The clinical presentation of this disease can be early (diagnosed in utero or immediately after birth) or late (diagnosed during the first 3-4 months of life) [1]. Early diagnosis is done based on prenatal US findings and is associated with a higher survival rate. However limited awareness of this disease and low suspicion by physicians makes the early diagnosis rare. Serial US starting at 20 weeks are highly recommended to follow up the disease in the presence of risk factors or a positive family history [6]. Prenatal US are the modality of choice for diagnosis and may be significant for polyhydramnios, pleural and pericardial effusion, and non-immune fetal hydrops. US and CT scans are more sensitive in detecting the

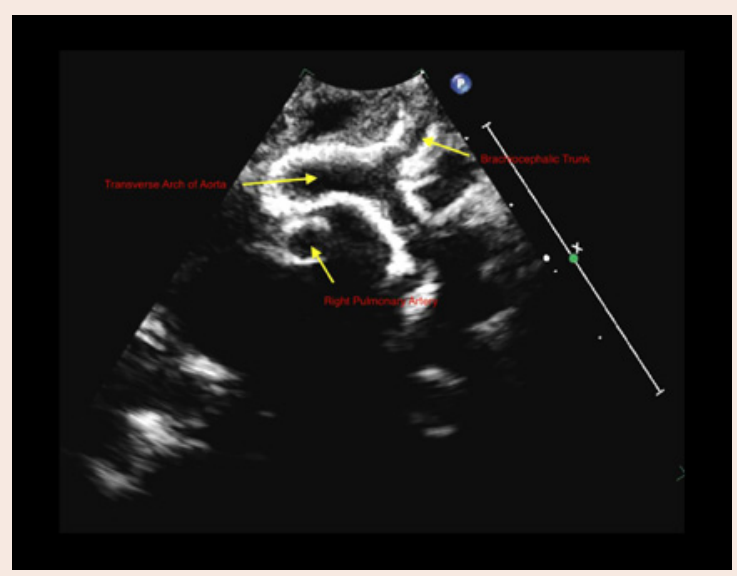

Figure 3: Figure showing calcification of the transverse arch of aorta 
Citation: Mahajan V, Sahni M, Dasgupta S, Amyn J, Jain SK. Idiopathic Calcification of Infancy-Case Report and Review of Literature. J Pediatr Child Care. 2016;2(1): 5.

ISSN: 2380-0534

Table 1: Reported cases of IIAC with pericardial effusion

\begin{tabular}{|c|c|c|c|c|c|}
\hline SI No & Presenting age & Presenting symptoms & Confirmation of diagnosis & Clinical Course & Reference \\
\hline 1. & In utero (28 wk) & $\begin{array}{l}\text { Prenatal US showed scalp and skin edema, bilateral } \\
\text { hydrocele, ascites with pleural and pericardial effusion. } \\
\text { Fetal ECHO showed that both ventricles were dilated } \\
\text { with severely depressed contractility. The aortic annulus, } \\
\text { ascending aorta, aortic arch, descending aorta, common } \\
\text { iliac arteries, main pulmonary artery, tricuspid valve, and } \\
\text { mitral chordae tendinae were hyperechogenic. Right } \\
\text { ventricular outflow tract was narrow with decreased } \\
\text { blood flow. }\end{array}$ & $\begin{array}{c}\text { US and histology at the time of } \\
\text { autopsy }\end{array}$ & $\begin{array}{c}\text { Pregnancy terminated } \\
\text { due to unfavorable } \\
\text { prognosis }\end{array}$ & [13] \\
\hline 2. & In utero (22 weeks) & $\begin{array}{c}\text { Twin B with polyhydramnios, hypertrophic } \\
\text { cardiomyopathy and large pericardial effusion. Fetal } \\
\text { Echo revealed hyperechogenicity suggestive of } \\
\text { calcification of ascending and upper descending } \\
\text { thoracic aorta and central pulmonary arteries. Systemic } \\
\text { hypertension dueing first month of life }\end{array}$ & $\begin{array}{l}\text { Congenital } \mathrm{ECHO} \text { with } \\
\text { aortopulmonary calcifications, } \\
\text { neonatal hypertension and } \\
\text { progressive cardiomyopathy }\end{array}$ & $\begin{array}{l}\text { Patient died at } 4.5 \\
\text { months of age }\end{array}$ & [14] \\
\hline 3. & $\begin{array}{c}\text { In utero } \\
(29 \text { weeks })\end{array}$ & $\begin{array}{c}\text { Prenatal US showed fetal hydrops (hydrothorax, } \\
\text { skin edema, ascites, pericardial effusion and } \\
\text { polyhydramnios), echogenic great arteries and } \\
\text { pathological Doppler findings }\end{array}$ & $\begin{array}{c}\text { Postmortem and genetic testing } \\
\text { confirmed a mutation in the } \\
\text { ENPP1 gene }\end{array}$ & $\begin{array}{c}\text { Early neonatal } \\
\text { death due to primary } \\
\text { intracranial hemorrhage }\end{array}$ & [15] \\
\hline 4. & In utero (30 weeks) & $\begin{array}{l}\text { Prenatal US showed polyhydramnios, pericardial and } \\
\text { pleural effusion and abdominal ascites. Fetal Echo } \\
\text { showed hyperechogenicity of right and left cardiac } \\
\text { outflow tract with idiopathic cardiomyopathy }\end{array}$ & $\begin{array}{l}\text { Molecular genetic testing was } \\
\text { negative. Parents declined } \\
\text { histological testing }\end{array}$ & $\begin{array}{l}\text { Neonate died at } 10 \\
\text { days of life due to heart } \\
\text { failure }\end{array}$ & [16] \\
\hline 5. & In utero (28 weeks) & $\begin{array}{l}\text { Prenatal US showed hyper echogenicity of aortic wall, } \\
\text { heart walls, common iliac arteries and kidneys. Also } \\
\text { showed ascites, pericardial effusion and biventricular } \\
\text { hypofunction }\end{array}$ & $\begin{array}{l}\text { Molecular genetic testing was } \\
\text { negative. Parents declined } \\
\text { histological testing }\end{array}$ & $\begin{array}{c}\text { Fetal demise at } 32 \\
\text { weeks }\end{array}$ & [16] \\
\hline 6. & In utero (33 weeks) & $\begin{array}{l}\text { Prenatal US revealed polyhydramnios, IUGR, pericardial } \\
\text { effusion, increased renal cortical echogenicity with } \\
\text { sparing of corticomedullary differentiation, and diffuse } \\
\text { arterial calcifications involving the aorta, pulmonary } \\
\text { artery, common iliac arteries, renal arteries, and } \\
\text { common carotid arteries. }\end{array}$ & $\mathrm{N} / \mathrm{A}$ & $\begin{array}{l}\text { Death at } 4 \text { months } \\
\text { of life }\end{array}$ & [17] \\
\hline 7. & $\begin{array}{l}\text { In utero } \\
(33 \text { weeks })\end{array}$ & $\begin{array}{c}\text { Prenatal US notable for hydropsfetalis with } \\
\text { polyhydramnios, a pericardial effusion and echogenic } \\
\text { cardiac outflow tracts. Fetal echocardiography revealed } \\
\text { cardiomegaly with hypertrophy and decreased } \\
\text { biventricular function. }\end{array}$ & $\begin{array}{l}\text { Calcifications confirmed with } \\
\text { post mortem CT scans and } \\
\text { autopsy }\end{array}$ & $\begin{array}{l}\text { Neonatal demise on } \\
\text { day } 1 \text { of life }\end{array}$ & [18] \\
\hline 8. & In utero (33 weeks) & $\begin{array}{l}\text { Prenatal US shows severe polyhydramnios, echogenic } \\
\text { aortic wall and cardiac outflow tracts, pericardial } \\
\text { effusion, a large atrial septal defect, bilateral pleural } \\
\text { effusion, ascites, subcutaneous edema and echogenic } \\
\text { kidneys }\end{array}$ & Histology at autopsy & $\begin{array}{c}\text { Intrauterine fetal } \\
\text { demise at } 34 \text { weeks }\end{array}$ & [19] \\
\hline 9. & $\begin{array}{c}\text { In utero } \\
(29 \text { weeks })\end{array}$ & $\begin{array}{l}\text { Prenatal US at } 29 \text { weeks showed } \\
\text { Intracardiac calcifications and pericardial effusion. At } 32 \\
\text { weeks there was aortic calcifications along with diffuse } \\
\text { abdominal and placental calcifications }\end{array}$ & $\begin{array}{l}\text { Chorionic villus sampling } \\
\text { showed ENPP1 mutations }\end{array}$ & $\begin{array}{l}\text { Delivered at } 32 \text { weeks } \\
\text { and died in } 12 \text { hours } \\
\text { due to myocardial } \\
\text { infarction }\end{array}$ & [20] \\
\hline 10. & $\begin{array}{l}\text { In utero } \\
(27 \text { weeks })\end{array}$ & $\begin{array}{l}\text { Prenatal US showed polyhydramnios, pleural effusion, } \\
\text { pericardial effusion scalp edema, abdominal wall edema, } \\
\text { right ventricle dilation along with hyperechogenic aortic } \\
\text { wall, common iliac arteries, main pulmonary artery, } \\
\text { bilateral } \\
\text { renal arteries and echogenic renal parenchyma }\end{array}$ & Autopsy not done & Stillbirth at 29 weeks & [21] \\
\hline 11. & In utero (32 weeks) & $\begin{array}{l}\text { Prenatal US showed polyhydramnios . Fetal ECHO } \\
\text { revealed echodense aortic annulus, ascending aorta, } \\
\text { transverse arch, descending aorta, main pulmonary } \\
\text { artery, and coronary arteries. Biventricular dilatation with } \\
\text { depressed function and a small pericardial effusion. }\end{array}$ & Histopathology at autopsy & Fetal demise & [22] \\
\hline 12. & $\begin{array}{l}\text { In utero } \\
(29 \text { weeks })\end{array}$ & $\begin{array}{c}\text { Prenatal US showed fetal hydrops with pericardial } \\
\text { effusion. Congenital ECHO done showed cardiomegaly, } \\
\text { hyperechogenic ascending and descending aorta }\end{array}$ & Histopathology on autopsy & $\begin{array}{l}\text { Died on day } 24 \text { of life } \\
\text { due to heart failure. }\end{array}$ & [23] \\
\hline 13. & $\begin{array}{l}\text { In utero }(292 / 7 \\
\text { weeks)- sibling of } \\
\text { previous case }\end{array}$ & $\begin{array}{c}\text { Fetal ECHO revealed severe myocardial dysfunction, } \\
\text { pericardial effusion, regurgitation of } \mathrm{AV} \text { valves along } \\
\text { with hyperechogenicity of atria walls, AV valves and } \\
\text { ascending aorta }\end{array}$ & Histopathology on autopsy & $\begin{array}{l}\text { Died at } 1 \text { hour of life } \\
\text { due to heart failure. }\end{array}$ & [23] \\
\hline
\end{tabular}




\begin{tabular}{|c|c|c|c|c|c|}
\hline 14. & $\begin{array}{c}\text { In utero } \\
\text { (28 } 4 / 7 \text { weeks) }\end{array}$ & $\begin{array}{l}\text { Prenatal US showed polyhydramnios, } \\
\text { Pericardial effusion, intracardiac calcifications, poorly } \\
\text { contracting right ventricle along with hyperechogenic } \\
\text { aorta and pulmonary arteries }\end{array}$ & Histopathology on autopsy & $\begin{array}{l}\text { Died at } 33 \text { days of life } \\
\text { due to heart failure }\end{array}$ & [24] \\
\hline 15. & $\begin{array}{c}\text { In utero } \\
(325 / 7 \text { weeks })\end{array}$ & $\begin{array}{l}\text { Prenatal US showed fetal hydrops, } \\
\text { pericardial effusion, decreased myocardial } \\
\text { contractility and hyperechoic arteries. }\end{array}$ & Histopathology on autopsy & $\begin{array}{c}\text { Died at } 34 \text { min after } \\
\text { birth }\end{array}$ & [25] \\
\hline 16. & $\begin{array}{c}\text { In utero } \\
(33 \text { weeks })\end{array}$ & $\begin{array}{l}\text { Fetal ECHO showed hyperechogenicity of great vessels, } \\
\text { pericardial effusion along with polyhydramnios noted on } \\
\text { prenatal US }\end{array}$ & Parents denied autopsy & $\begin{array}{l}\text { Died at } 5 \text { weeks of life } \\
\text { due to heart failure }\end{array}$ & {$[26]$} \\
\hline 17. & $\begin{array}{c}\text { In utero } \\
\text { (33-34 weeks) }\end{array}$ & $\begin{array}{l}\text { Prenatal US showed polyhydramnios, large pleural and } \\
\text { pericardial effusions along with possible calcification } \\
\text { of aorta and its branches. Follow up imaging after birth } \\
\text { confirmed widespread generalized calcification }\end{array}$ & N/A & $\begin{array}{l}\text { Died at day } 16 \text { of life } \\
\text { due to heart failure }\end{array}$ & {$[27]$} \\
\hline
\end{tabular}

calcifications in the vessels due to the higher contrast resolution. Calcifications of the long bones may be visible on plain radiographs and a high suspicion of IIAC should be maintained in an infant presenting with calcifications associated with persistent refractory hypertension or cardiac failure [6]. Table 1 lists all the reported cases of IIAC with pericardial effusion at the time of presentation. Increased echogenicity of the aorta and outflow tract (representing calcifications) along with narrowing of the coronary artery may be noted on ECHO and warrant closer follow up and monitoring. Late onset IIAC presents with non-specific findings such as respiratory distress, cyanosis, poor feeding, vomiting, and failure to thrive [1].

A definite diagnosis of IIAC involves identification of bi-allelic pathogenic variants in ENPP1 or ABCC6 or typical histologic findings on arterial biopsyif molecular genetic testing is not diagnostic [7]. The commonly associated gene, ENPP1 (Ectonucleotide pyrophosphatase/phosphodiesterase) is located on chromosome 6q22-23 [8]. Pyrophosphate is one of the inhibitors of physiological calcification. Its production is regulated by enzyme activity controlled by the ENPP1 gene. Therefore, a mutation in this gene leads to decreased pyrophosphate levels which in turn cause unregulated production and deposition of hydroxyapatite crystals within the vessel walls [9]. Histology which is the gold standard [10], may reveal hypertrophy of the myocardium and subendocardial fibrosis. Histologically, hydroxyapatite crystal deposition with calcification and proliferation is seen in the internal elastic lamina of the large and medium vessels leading to arterial stenosis and subsequent organ failure secondary to ischemia. This process has been known to involve the coronary and renal arteries. Although the cerebral arteries are usually spared [6], there have been documented cases of cerebral artery involvement resulting in seizures, recurrent transient ischemic attacks and strokes [7]. Coronary artery involvement is considered to be a poor prognostic factor [1].

\section{Treatment}

Bisphosphonates are the treatment of choice for IIAC. Resolution of calcifications on CT scans/US has been documented at 4 months to 2 years after starting therapy without further recurrence. Peritoneal dialysis as a treatment for refractory hypertension has been reported and is thought to work by eliminating renin in the dialysate [11]. Cardiac surgery and [12] transplantation have been suggested as alternative modes of therapy for infants in cardiac failure.

\section{Conclusion}

IIAC should be suspected in infants presenting with hypertension and evidence of generalized calcification in blood vessels on imaging. Early diagnosis and treatment improves prognosis. This condition however remains a diagnosis of exclusion after ruling out more common causes of hypertension. A lot remains to be known about the management of this rare condition. Elucidating possible genes involved in this condition may lead to newer approaches towards therapy.

\section{References}

1. Bolster F, Ali Z, Southall P, Fowler D (2015) Generalized arterial calcification of infancy--Findings at post-mortem computed tomography and autopsy. Forensic Sci Int 254: e7-e12.

2. Pejovic B, Peco-Antic A, Marinkovic-Eric J (2007) Blood pressure in noncritically ill preterm and full-term neonates. Pediatr Nephrol 22: 249-257.

3. Colan SD, McElhinney DB, Crawford EC, Keane JF, Lock JE (2006) Validation and re-evaluation of a discriminant model predicting anatomic suitability for biventricular repair in neonates with aortic stenosis. J Am Coll Cardiol 47: 1858-1865

4. Sahay S, Tonelli AR (2013) Pericardial effusion in pulmonary arterial hypertension. Pulm Circ 3: 467-477.

5. Glatz AC, Pawel BR, Hsu DT, Weinberg P, Chrisant MR (2006) Idiopathic infantile arterial calcification: two case reports, a review of the literature and a role for cardiac transplantation. Pediatr Transplant 10: 225-233.

6. Nasrallah FK, Baho H, Sallout A, Qurashi M (2009) Prenatal diagnosis of idiopathic infantile arterial calcification with hydrops fetalis. Ultrasound Obstet Gynecol 34: 601-604

7. Ferreira C, Ziegler S, Gahl W (1993) Generalized arterial calcification of infancy. In: Pagon RA, Adam MP, Ardinger HH, et al. (Eds). GeneReviews $₫$ [Internet]. Seattle (WA): University of Washington, Seattle.

8. Nitschke Y, Rutsch F (2012) Genetics in arterial calcification: lessons learned from rare diseases. Trends Cardiovasc Med 22: 145-149.

9. Numakura C, Yamada M, Ariyasu D, Maesaka A, Kobayashi H, et al. (2006) Genetic and enzymatic analysis for two Japanese patients with idiopathic infantile arterial calcification. J Bone Miner Metab 24: 48-52.

10. Shaireen H, Howlett A, Amin H, Yusuf K, Kamaluddeen M, et al. (2013) The mystery of persistent pulmonary hypertension: an idiopathic infantile arterial calcification. BMC Pediatr 13: 107

11. Stojanovic V, Doronjski A, Milakb G, Barisic N (2013) Idiopathic arterial calcification of infancy-peritoneal dialysis for treatment of hypertension. Fetal Pediatr Pathol 32: 443-447.

12. Samyn MM, Bick D, Humphrey JA, Gandy KL (2010) Successful congenital heart surgery for a toddler with idiopathic infantile arterial calcification. Pediatr Cardiol 31: 1096-1099.

13. Corbacioglu Esmer A, Kalelioglu I, Omeroglu RE, Kayserili H, Gulluoglu $\mathrm{M}$, et al. (2015) Prenatal ultrasonographic diagnosis of generalized arterial calcification of infancy. J Clin Ultrasound 43: 50-54. 
Citation: Mahajan V, Sahni M, Dasgupta S, Amyn J, Jain SK. Idiopathic Calcification of Infancy-Case Report and Review of Literature. J Pediatr Child Care. 2016;2(1): 5.

ISSN: 2380-0534

14. Samon LM, Ash KM, Murdison KA (1995) Aorto-pulmonary calcification: an unusual manifestation of idiopathic calcification of infancy evident antenatally. Obstet Gynecol 85(5 Pt 2): 863-865.

15. Reitter A, Fischer D, Buxmann H, Nitschke Y, Rutsch F, et al. (2009) Fetal hydrops, hyperechogenic arteries and pathological doppler findings at 29 weeks: prenatal presentation of generalized arterial calcification of infancy - a novel mutation in ENPP1. Fetal Diagn Ther 25: 264-268.

16. Mastrolia SA, Weintraub AY, Baron J, Sciaky-Tamir Y, Koifman A, et al (2015) Antenatal diagnosis of idiopathic arterial calcification: a systematic review with a report of two cases. Arch Gynecol Obstet 291: 977-986.

17. Cansu A, Ahmetoglu A, Mutlu M, Guven S, Osmanagaoglu MA (2010) Idiopathic infantile arterial calcification: prenatal diagnosis and postnata presentation. Clin Exp Obstet Gynecol 37: 73-75.

18. Heuser CC, Puchalski M, Kennedy A, Sangle N, Manuck T, et al. (2010) Radiographic and pathologic evaluation of idiopathic infantile arterial calcification. Obstet Gynecol 115(2 Pt 2): 465-468.

19. Nagaraj BR, Jain $P$, Thomas DA, Raghu M (2009) Sonological appearance of idiopathic arterial calcification in fetus: A rare case. Indian J Radiol Imaging 19: $248-251$

20. Dlamini N, Splitt M, Durkan A, Siddiqui A, Padayachee S, et al. (2009) Generalized arterial calcification of infancy: phenotypic spectrum among three siblings including one case without obvious arterial calcifications. Am J Med Genet A 149A: 456-460.

21. Nagar AM, Hanchate V, Tandon A, Thakkar H, Chaubal NG (2003) Antenatal detection of idiopathic arterial calcification with hydrops fetalis. J Ultrasound Med 22: 653-659

22. Levine JC, Campbell J, Nadel A (2001) Image in cardiovascular medicine. Prenatal diagnosis of idiopathic infantile arterial calcification. Circulation 103: 325-326.

23. Eronen M, Pohjavuori M, Heikkilä P (2001) Fatal outcome of two siblings with idiopathic arterial calcification of infancy diagnosed in utero. Pediatr Cardio 22: $167-169$

24. Crade M, Lewis DF, Nageotte MP (1991) In utero appearance of idiopathic infantile arterial calcification: ultrasound study of a 28 -week fetus. Ultrasound Obstet Gynecol 1: 284-285.

25. Spear R, Mack LA, Benedetti TJ, Cole RE (1990) Idiopathic infantile arterial calcification. In utero diagnosis. J Ultrasound Med 9: 473-476.

26. Stuart G, Wren C, Bain H (1990) Idiopathic infantile arterial calcification in two siblings: failure of treatment with diphosphonate. Br Heart J 64: 156-159.

27. Tschumper B, Dietrich RB, Pais MJ, Crade M (1994) Pediatric case of the day. Idiopathic infantile arterial calcification (IIAC). Radiographics 14: 675677 